\title{
Diagnosis of Urinary Tract Infection in Childhood Based on Examination of Paired Non-catheter and Catheter Specimens of Urine
}

\author{
H. BRAUDE,* M.B., CH.B., M.R.C.P.ED., D.C.H. ; J. O. FORFAR,* M.C., M.D., B.SC., F.R.C.P., F.R.C.P.ED., D.C.H. \\ J. C. GOULD,† M.D., B.SC., F.R.C.P.ED., M.C.PATH., F.R.S.ED. ; J. W. MCLEOD, $†$ O.B.E., M.B., CH.B., F.R.S.
}

Brit. med. F., 1967, 4, 702-705

The accurate diagnosis of urinary tract infection. in infancy and childhood based on examination of the urine is made difficult by the number of variables involved. These include the age and sex of the patient, method of collection of the urine, time interval between micturition and urine examination, and technique of examination employed. The method of collection of urine is most important and for two common methodsplastic adhesive bags and midstream specimens-we have suggested diagnostic levels for cell and bacterial counts related to the age and sex of the patient and the type of collection (Braude et al., 1967).

To determine the validity of these levels non-catheter and atheter specimens of urine were obtained from 68 patients.

\section{Material}

In most of the patients the suspicion had arisen on clinical grounds that urinary tract infection might be present-a suspicion based on suggestive symptoms such as abdominal pain, dysuria, frequency of micturition, enuresis, unexplained romiting or anorexia, and, in the case of infants, unexplained failure to thrive. Also in a number of symptomless cases routine examination of the urine had suggested that infection might be present. Of the 68 patients 49 were female and 19 male. The ages ranged from 9 days to 11 years (see Table).

\section{Methods}

With the methods described by Braude et al. (1967) 92 nonatheter specimens-76 (82\%) midstream and $16(18 \%)$ bag*ere obtained from 68 patients, and thereafter a catheter specimen was obtained from each of them. Catheterization was sarried out by a modification of the technique described by McLeod et al. (1963), which is effective in delaying urinary ract infection in paraplegic patients, often for many weeks, If a daily change of catheter is made. The external genitalia, ufter washing with sterile water and while still moist, are prayed with Polybactrin (neomycin sulphate $495 \mathrm{mg}$., polymyxin B sulphate 150,000 units, zinc bacitracin 37,500 units, nade up to $109 \mathrm{~g}$. with a mixture of the inert and highly volatile fluids dichlorotetrafluoroethane and dichlorodifluoromethane) from a distance of 12 in. $(30 \mathrm{~cm}$.), the labia being separated in the female and the foreskin retracted in the male. The perineum is then covered with a sterile towel.

The urethra is irrigated with aqueous Polybactrin Soluble G.U., consisting of bacitracin 1,000 units, neomycin sulphate $20 \mathrm{mg}$., and polymyxin B sulphate 75,000 units per $2 \mathrm{ml}$. With the use of forceps, a catheter fine enough to allow a free return flow (a sterile disposable premature infant-feeding tube size 5 French is suitable) is inserted into the anterior urethra, in females just being allowed to enter the anterior urethra and in males being introduced up to $\frac{1}{2}$ in. $(1.3 \mathrm{~cm}$.). While the

\footnotetext{
- Department of Child Life and Health. University of Edinburgh and Western General Hospital, Edinburgh.

+Central Microbiological Laboratories, Edinburgh.
}

operator holds the catheter in position an assistant slowly injects $2 \mathrm{ml}$. of solution. A return flow alongside the catheter should occur. (If it does not the catheter has been inserted too far and the solution is being injected into the bladder. This may modify bacteriological but not cytological results.) The catheter is then withdrawn and the patient left for half an hour. In young boys catheterization often causes discomfort and it is advisable to anaesthetize the posterior urethra before the second or main part of the catheterization procedure by introducing a little anaesthetic jelly (Duncaine) into the urethra immediately after the irrigation procedure.

After half an hour has elapsed the operator again scrubs up and, holding the labia apart or retracting the foreskin, using sterile swabs, the genitalia are resprayed with Polybactrin as described above and the patient is retowelled. The operator puts on sterile gloves and catheterizes the bladder, using a sterile disposable plastic tube size 9 F.G. (feeding or umbilical tube) and a non-touch technique. The assistant, controlling the other end of the catheter with forceps, directs thr urine into a sterile container. Normally a few drops are collected into a first bottle, which is discarded, and the remainder of the urine into a second. In small babies there may be little urine in the bladder, and under these circumstances the first bottle has to be used for bacteriological examinations.

\section{Effect of Polybactrin Catheterization on Bacterial Growth in the Urine}

In most cases the antibacterial activity of the urine obtained after catheterization was determined by means of indicator plates sown with an antibiotic-sensitive staphylococcus and filter-paper discs saturated with urine (Gould, 1965). Such: activity was shown in $69 \%$ of specimens, and the avarage zone of elimination was $5-6 \mathrm{~mm}$. This is a very limited antibacteria: effect. Experience with this method shows that it is unusual to find bacterial counts in the lower range of $10^{3}$ or $10^{4} / \mathrm{m}$ ] If a growth is obtained it is usually of the order of $10^{5} \mathrm{o}$ greater $/ \mathrm{ml}$. This clear differentiation is probably due to the mild antibacterial effect of the Polybactrin in the urine inhibit. ing growth of contaminants. With this technique a bacterial count of $10^{4}$ or higher $/ \mathrm{ml}$. was considered to indicate infection

As regards cell counts in catheterized patients infection was reckoned to be present if the count exceeded $10 / \mathrm{cu} . \mathrm{mm}$.

\section{Results}

Cell counts, bacterial counts, organisms cultured, and urinary $\mathrm{pH}$ are shown in the Table. The criteria for infection in catheter specimens were either or both of the cell and bacterial counts given above and, for non-catheterized specimens, one or more of the cell counts, bacterial counts, and combined cell and bacterial counts ("combined counts") given by Braude et al. (1967) as indicative of infection. In columns 7, 8 , and 9 of the Table positive or negative signs indicate whether or not these criteria were met. 
Summary of Results

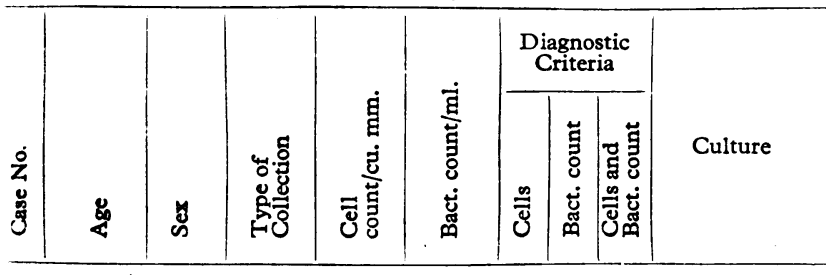

药

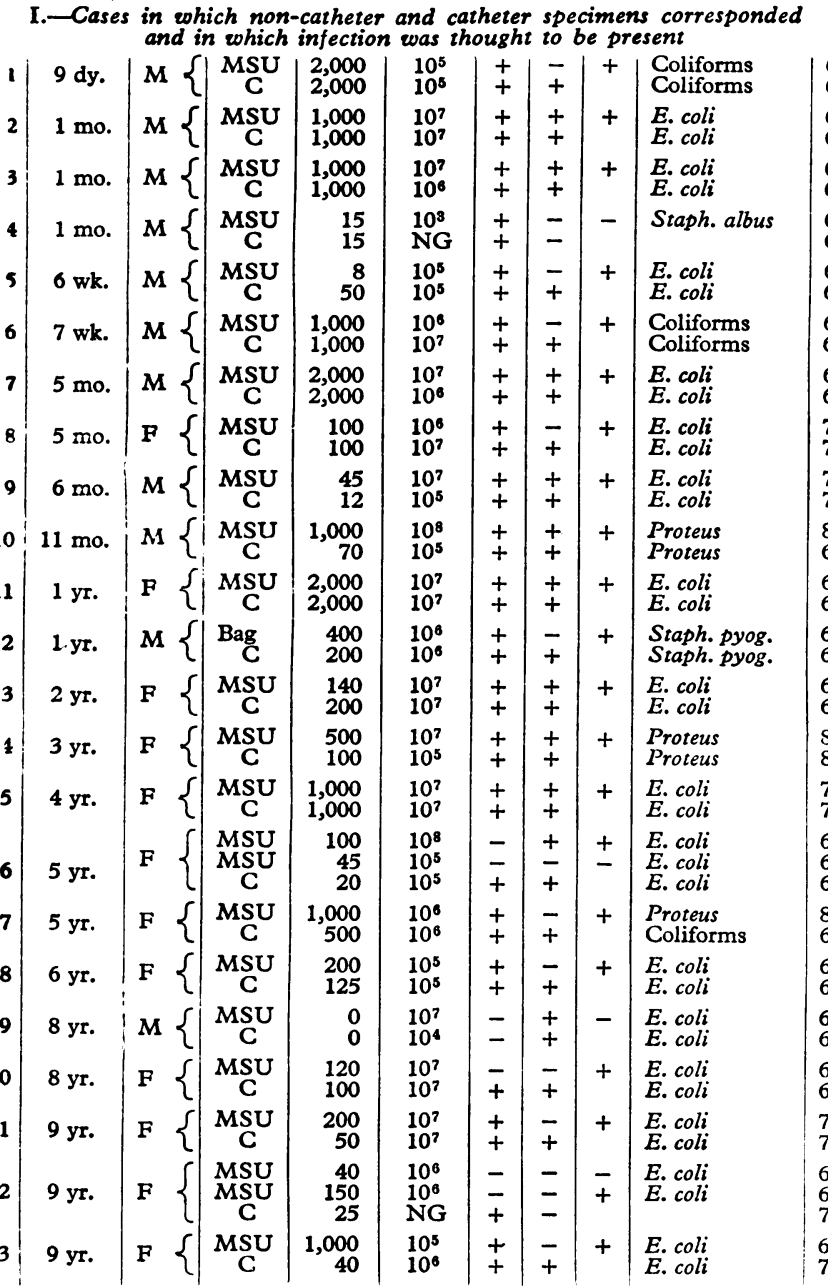

II.-Cases in which non-catheter and catheter specimens corresponded

\begin{tabular}{|c|c|c|c|c|c|c|c|c|c|}
\hline & & $\mathrm{F}=$ & Bag & 125 & $10^{5}$ & - & - & - & E. coli; Proteus \\
\hline 24 & $10 \mathrm{dy}$. & $\mathrm{F}$ & Cे & 1 & NG & - & - & & 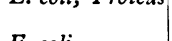 \\
\hline 25 & $11 \mathrm{dy}$. & $M\{$ & MSU & $\begin{array}{l}2 \\
0 \\
0\end{array}$ & $\begin{array}{l}10^{5} \\
\text { NG }\end{array}$ & $\bar{z}$ & $\bar{z}$ & $\overline{-}$ & $\begin{array}{l}\text { E. colt } \\
\text { E. coli }\end{array}$ \\
\hline 26 & $13 \mathrm{dy}$. & $\mathbf{F}$ & Bag & $\begin{array}{r}27 \\
0\end{array}$ & $\begin{array}{l}10^{3} \\
\text { NG }\end{array}$ & $\bar{z}$ & $\overline{-}$ & - & E. coli; Proteus \\
\hline 27 & 2 wk. & F & $\begin{array}{l}\mathrm{Bag} \\
\mathrm{MSO} \\
\mathrm{C}\end{array}$ & $\begin{array}{l}0 \\
0 \\
0\end{array}$ & $\begin{array}{l}10^{6} \\
10^{6} \\
\text { NG }\end{array}$ & $\bar{z}$ & $\bar{z}$ & $\overline{-}$ & $\begin{array}{l}\text { E. coli } \\
\text { E. coli }\end{array}$ \\
\hline & & & $M S U$ & 0 & $10^{4}$ & - & - & - & $\begin{array}{l}\text { Str. faec.; } \\
\text { Staph pyog. }\end{array}$ \\
\hline 28 & 2 wk. & F & $\begin{array}{l}\text { MSU } \\
\text { Bag } \\
\text { C }\end{array}$ & $\begin{array}{l}0 \\
2\end{array}$ & $\begin{array}{l}10^{5} \\
10^{4}\end{array}$ & $\bar{z}$ & $\bar{z}$ & $\overline{-}$ & $\begin{array}{l}\text { Proteus } \\
\text { Proteus; Str. } \\
\quad \text { faec.; E. coli }\end{array}$ \\
\hline 29 & $1 \mathrm{mo}$. & & $\mathrm{Bag}$ & $\begin{array}{r}100 \\
0\end{array}$ & $\begin{array}{l}10^{5} \\
\text { NG }\end{array}$ & $\bar{z}$ & $\bar{z}$ & - & E. coli \\
\hline 10 & $4 \mathrm{mo}$. & & $\begin{array}{l}\text { Bag } \\
\text { C } \\
\text { MSU }\end{array}$ & $\begin{array}{l}0 \\
0 \\
0\end{array}$ & $\begin{array}{l}10^{3} \\
\text { NG } \\
10^{5}\end{array}$ & $\bar{z}$ & $\bar{z}$ & - & $\begin{array}{l}\text { E. coli } \\
\text { Proteus; }\end{array}$ \\
\hline 31 & $5 \mathrm{mo}$. & $\mathbf{M}$ & MSU & 0 & $10^{5}$ & - & - & - & $\begin{array}{l}\text { Str. faec. } \\
\text { Proteus; } \\
\text { Str. faec. }\end{array}$ \\
\hline & & & $\begin{array}{c}\text { MSU } \\
\text { C }\end{array}$ & 0 & NG & - & - & - & $\begin{array}{l}\text { Proteus; } \\
\text { Str. faec. }\end{array}$ \\
\hline & $5 \mathrm{mo}$. & $\mathbf{F}$ & $\stackrel{\mathrm{MSU}}{\mathrm{C}}$ & $\begin{array}{l}2 \\
0\end{array}$ & $\begin{array}{l}10^{5} \\
N G\end{array}$ & $\overline{-}$ & $\overline{-}$ & - & E. coli \\
\hline & $5 \mathrm{mo}$. & $\mathbf{F}$ & Bag & $\begin{array}{r}16 \\
0\end{array}$ & $\begin{array}{l}10^{5} \\
\text { NG }\end{array}$ & $\overline{-}$ & $\overline{-}$ & - & Proteus \\
\hline & $5 \mathrm{mo}$. & F & $\begin{array}{l}\text { Bag } \\
\text { Bag } \\
\text { C }\end{array}$ & $\begin{array}{r}20 \\
10 \\
0\end{array}$ & $\begin{array}{l}10^{6} \\
10^{5} \\
\text { NG }\end{array}$ & $\bar{z}$ & $\bar{z}$ & $\bar{z}$ & $\begin{array}{l}\text { E. coli } \\
\text { Staph. albus }\end{array}$ \\
\hline & $6 \mathrm{mo}$. & $\mathbf{F}\{$ & $\underset{\mathrm{CSU}}{\mathrm{MSU}}$ & $\begin{array}{l}0 \\
0\end{array}$ & $\stackrel{10^{8}}{\mathrm{NG}}$ & $\overline{-}$ & $\overline{-}$ & - & Staph. pyog. \\
\hline
\end{tabular}

Summary of Results-Continued

\begin{tabular}{|c|c|c|c|c|c|c|c|c|c|c|}
\hline \multirow[b]{2}{*}{$\begin{array}{l}\dot{2} \\
\dot{z} \\
\dot{u} \\
\text { Jै }\end{array}$} & \multirow[b]{2}{*}{$\stackrel{\circ}{<}$} & \multirow[b]{2}{*}{ फ़ } & \multirow[b]{2}{*}{ 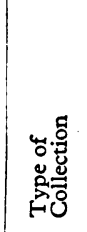 } & \multirow[b]{2}{*}{ 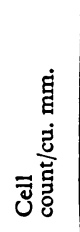 } & \multirow[b]{2}{*}{ 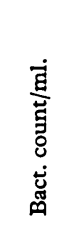 } & \multicolumn{3}{|c|}{$\begin{array}{c}\text { Diagnostic } \\
\text { Criteria }\end{array}$} & \multirow[b]{2}{*}{ Culture } & \\
\hline & & & & & & $\stackrel{\infty}{\bar{z}}$ & $\begin{array}{l}\tilde{\Xi} \\
\dot{J} \\
\dot{\tilde{g}} \\
\ddot{m}\end{array}$ & 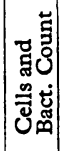 & & 窝 \\
\hline & & & $\begin{array}{l}\text { Bag } \\
\text { MSU }\end{array}$ & $\begin{array}{l}0 \\
0\end{array}$ & $\begin{array}{l}10^{5} \\
10^{4}\end{array}$ & $\overline{-}$ & $\overline{-}$ & $\overline{-}$ & $\begin{array}{l}\text { Proteus } \\
\text { Proteus; }\end{array}$ & $\begin{array}{l}6 \\
6\end{array}$ \\
\hline 36 & $7 \mathrm{mo}$. & $M$ & MSU & 0 & $10^{5}$ & - & - & - & $\begin{array}{l}\text { Str. faec. } \\
\text { Proteus; } \\
\text { Str. faec. }\end{array}$ & 6 \\
\hline 37 & $7 \mathrm{mo}$. & & $\underset{\mathrm{C}}{\mathrm{C}}$ & $\begin{array}{l}0 \\
0 \\
0\end{array}$ & $\begin{array}{l}\text { NG } \\
10^{6} \\
\text { NG }\end{array}$ & $\bar{z}$ & $\bar{z}$ & - & Proteus & $\begin{array}{l}6 \\
6\end{array}$ \\
\hline 38 & $8 \mathrm{mo}$. & $F$ & $\begin{array}{c}\text { MSU } \\
\mathrm{C}\end{array}$ & $\begin{array}{l}1 \\
0\end{array}$ & $\begin{array}{l}10^{5} \\
\mathrm{NG}\end{array}$ & - & - & - & $\begin{array}{l}\text { Proreus; } \\
\text { Str. faec. }\end{array}$ & $\begin{array}{l}6 \\
6\end{array}$ \\
\hline & & & Bag & 0 & $10^{5}$ & - & - & - & $\begin{array}{l}\text { Coliforms; } \\
\text { Proteus }\end{array}$ & \\
\hline 39 & $10 \mathrm{mo}$. & & $\underset{\mathrm{C}}{\mathrm{MSU}}$ & $\begin{array}{l}0 \\
0 \\
0\end{array}$ & $\begin{array}{l}10^{8} \\
N G \\
10^{8}\end{array}$ & $\bar{z}$ & $\bar{z}$ & - & Proteus & \\
\hline 40 & $10 \mathrm{mo}$. & & $\begin{array}{l}\text { MSU } \\
\text { MSU }\end{array}$ & $\begin{array}{r}0 \\
0 \\
30\end{array}$ & $\begin{array}{l}10^{6} \\
N_{10}^{4}\end{array}$ & $\bar{z}$ & $\bar{z}$ & - & $\begin{array}{l}\text { E. coli } \\
\text { Proteus }\end{array}$ & \\
\hline 41 & $1 \mathrm{yr}$. & $\mathrm{F}\{$ & $\begin{array}{l}\text { MSU } \\
\text { MSU }\end{array}$ & $\begin{array}{l}0 \\
0 \\
0\end{array}$ & $\begin{array}{l}10^{3} \\
10^{5} \\
N G\end{array}$ & $\bar{z}$ & $\bar{z}$ & $\overline{-}$ & $\begin{array}{l}\text { Proteus } \\
\text { Proteus }\end{array}$ & \\
\hline 42 & $2 \mathrm{yr}$. & F & $\begin{array}{l}\text { MSU } \\
\text { MSU }\end{array}$ & $\begin{array}{l}0 \\
0\end{array}$ & $\begin{array}{l}10^{5} \\
10^{5}\end{array}$ & $\overline{-}$ & $\overline{-}$ & $\overline{-}$ & $\begin{array}{l}\text { E. coli } \\
\text { E. coli; Str. } \\
\text { faec.; } \\
\text { Staph albus }\end{array}$ & $\begin{array}{l}6 \\
6\end{array}$ \\
\hline 43 & $2 \mathrm{yr}$. & $F$ & $\underset{\mathrm{MSU}}{\mathrm{Bag}}$ & $\begin{array}{l}0 \\
0 \\
3\end{array}$ & $\begin{array}{l}\text { NG } \\
10^{5} \\
10^{4}\end{array}$ & $\bar{z}$ & $\bar{z}$ & $\overline{-}$ & $\begin{array}{l}\text { Staph alous } \\
\text { Proteus } \\
\text { Proteus; } \\
\text { Str. faec. }\end{array}$ & 6 \\
\hline & & & $\begin{array}{c}\mathrm{C} \\
M S U\end{array}$ & $\begin{array}{r}0 \\
30\end{array}$ & $\begin{array}{r}<10^{3} \\
N G\end{array}$ & $\overline{-}$ & - & - & $\begin{array}{l}\text { Str. faec. } \\
\text { Proteus }\end{array}$ & $\begin{array}{l}6 \\
6\end{array}$ \\
\hline 44 & $2 \mathrm{yr}$. & $\mathrm{F}$ & $\begin{array}{c}\text { MSU } \\
\mathrm{C}\end{array}$ & 0 & $\begin{array}{l}10^{3} \\
\mathrm{NG}\end{array}$ & - & - & - & $\begin{array}{l}\text { E. coli; } \\
\text { Staph. albus. }\end{array}$ & 6 \\
\hline 45 & $3 \mathrm{yr}$. & $F\{$ & $\underset{\mathrm{C}}{\mathrm{MSU}}$ & $\begin{array}{l}0 \\
0 \\
0\end{array}$ & NG & $\overline{-}$ & $\overline{-}$ & - & Micrococcus & $\begin{array}{l}0 \\
6 \\
6\end{array}$ \\
\hline 46 & $5 \mathrm{yr}$. & F & $\begin{array}{l}\mathrm{MSU} \\
\mathrm{MSU} \\
\mathrm{CSU}\end{array}$ & $\begin{array}{l}0 \\
8 \\
0\end{array}$ & $\begin{array}{l}10^{7} \\
10^{7} \\
\mathrm{NG}\end{array}$ & $\bar{z}$ & $\bar{z}$ & $\overline{-}$ & $\begin{array}{l}\text { Str. faec. } \\
\text { Str. faec. }\end{array}$ & \\
\hline 47 & $5 \mathrm{yr}$. & $F\{$ & $\underset{\mathrm{C}}{\mathrm{MSU}}$ & $\begin{array}{r}0 \\
0 \\
30\end{array}$ & $\begin{array}{l}10^{6} \\
\text { NG }\end{array}$ & $\overline{-}$ & $\overline{-}$ & - & E. coli & $\begin{array}{l}7 \\
7\end{array}$ \\
\hline 48 & $5 \mathrm{yr}$. & F & $\begin{array}{l}\text { MSU } \\
\text { MSU } \\
\text { C }\end{array}$ & $\begin{array}{r}30 \\
10 \\
0\end{array}$ & $\begin{array}{l}10^{6} \\
N G \\
N G\end{array}$ & $\bar{z}$ & $\bar{z}$ & $\overline{-}$ & E. coli & \\
\hline 49 & $5 \mathrm{yr}$. & $M$ & ${ }_{\mathrm{C}}^{\mathrm{MSU}}$ & $\begin{array}{l}0 \\
0\end{array}$ & $\begin{array}{l}\text { NG } \\
\text { NG }\end{array}$ & $\bar{z}$ & $\bar{z}$ & - & & \\
\hline 50 & $7 \mathrm{yr}$. & $M$ & MSU & $\begin{array}{l}0 \\
0\end{array}$ & $\begin{array}{l}10^{4} \\
\text { NG }\end{array}$ & $\overline{-}$ & $\overline{-}$ & - & Coliforms & \\
\hline 51 & $8 \mathrm{yr}$. & $M$ & $\begin{array}{l}\text { MSU } \\
\text { MSU }\end{array}$ & $\begin{array}{r}3 \\
0 \\
12\end{array}$ & $\begin{array}{l}10^{4} \\
\text { NG } \\
10^{5}\end{array}$ & $\bar{z}$ & - & - & $\begin{array}{l}\text { E. coli } \\
\text { E. coli; }\end{array}$ & $\begin{array}{l}6 \\
7\end{array}$ \\
\hline 52 & $9 \mathrm{yr}$. & $\mathrm{F}$ & $\underset{\mathrm{C}}{\mathrm{MSU}}$ & $\begin{array}{l}0 \\
0 \\
5\end{array}$ & $\begin{array}{l}10^{5} \\
\text { NG }\end{array}$ & $=$ & $\overline{-}$ & - & $\begin{array}{l}\text { Str. foli faec. } \\
\text { E. }\end{array}$ & $\begin{array}{l}7 \\
7\end{array}$ \\
\hline 53 & $9 \mathrm{yr}$. & $\mathrm{F}$ & $\begin{array}{l}\text { MSU } \\
\text { MSU } \\
\text { C }\end{array}$ & $\begin{array}{l}5 \\
7 \\
0\end{array}$ & $\begin{array}{l}10^{5} \\
10^{5} \\
\text { NG }\end{array}$ & $\bar{z}$ & $\overline{-}$ & $\overline{-}$ & $\begin{array}{l}\text { E. coli } \\
\text { E. coli }\end{array}$ & 7 \\
\hline 54 & $11 \mathrm{yr}$. & $\mathrm{F}\{1$ & $\underset{\mathrm{C}}{\mathrm{MSU}}$ & $\begin{array}{l}0 \\
0\end{array}$ & $\begin{array}{l}10^{4} \\
\mathrm{NG}\end{array}$ & $\overline{-}$ & $\underline{-}$ & - & Coliforms & \\
\hline
\end{tabular}

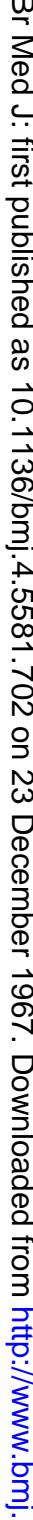

III-Non-catheter specimens showing infection: catheter specimens negativo

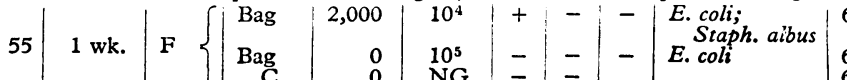

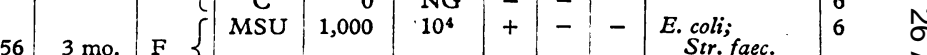

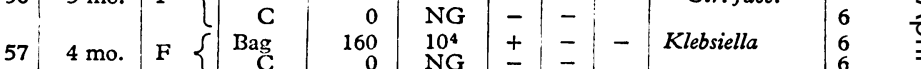

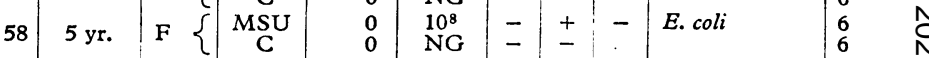

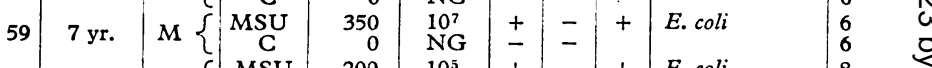

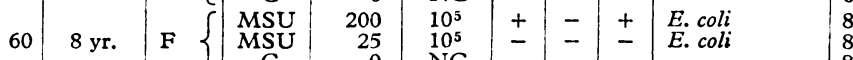

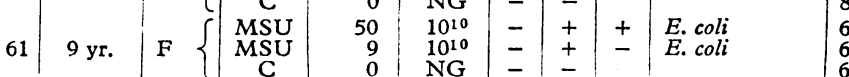
IV.-Non-catheter specimens negative: catheter specimens showing infection

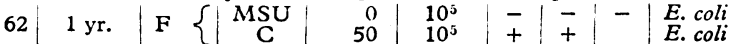

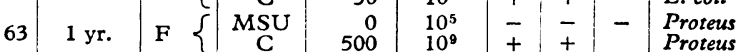

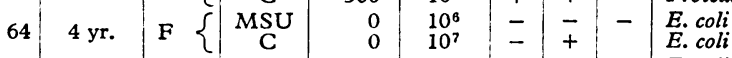

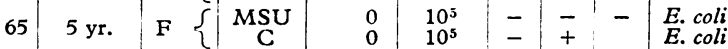
66 6 yr. F $\left\{\begin{array}{c|c|c|c|c|c|c|}\text { MSU } & 50 & 10^{4} & - & = & - & \text { E. coli } \\ \text { E. coli }\end{array}\right.$

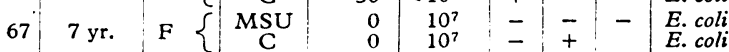

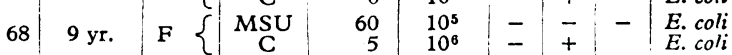


In making comparison between catheter and non-catheter urines evidence of infection in the catheter urine was considered to indicate genuine infection (with the exception of two cases mentioned later).

\section{Correlation between Non-catheter and Catheter Specimens}

The technique of catheterization should reduce to a minimum contamination with cells and bacteria and growth of any contaminant. The Polybactrin may even have caused some reduction in the bacterial count in infected cases. Thirty-nine $(57 \%)$ of the catheter urines showed no growth on culture. Twenty-nine $(43 \%)$ showed a growth-two with counts of less than $10^{3} / \mathrm{ml}$., one with a count of $10^{4} / \mathrm{ml}$, and the remainder with counts of $10^{5}$ or more $/ \mathrm{ml}$. In contrast only 3 of the 76 (4\%) midstream urines showed no growth and none of the 16 bag urines did so. The bacterial count in these urines ranged much more widely.

The Table is divided into four groups. The first of these contains 23 cases in which the urine was thought to show evidence of infection in both catheter and non-catheter specimens. In all but three of the catheter specimens (87\%) both cell count and bacterial count were "positive." In the noncatheter specimens all of the three possible criteria (cell count, bacterial count, and combined count) were positive in 9 cases (39\%), two in 10 cases ( $44 \%)$, and one in 4 cases $(17 \%)$. Combined counts alone were positive in 21 of the 23 cases $(92 \%)$, cell counts in 19 cases $(83 \%)$, and bacterial counts in 11 cases $(48 \%)$. Thus combined counts were most effective and single bacterial counts least effective in diagnosis.

In all 23 infected cases a single species of pathogens was isolated in pure culture, and, apart from one case in which the organisms were different and two in which in the catheter specimen there was no growth, the same organism was found in the catheter and non-catheter specimens.

The second group in the Table consists of 31 cases in which there was no evidence of infection, according to the criteria indicated above, in either catheter or non-catheter specimens. In these cases, in contradistinction to the infected cases, there were 12 in which a mixed flora was isolated or different species were obtained from catheter and non-catheter urines.

In the third group in the Table are seven cases in which the non-catheter specimen showed evidence of infection but the catheter specimen was negative. In five of these (Cases 55, 56, 57,58 , and 60 ) it seemed likely that the non-catheter specimens had given false-positive results. The symptomatology was unconvincing, the criteria were only minimally positive, a subsequent specimen in two of them was negative or there was a mixed growth. In two (Cases 59 and 61) the findings in the non-catheter urine were probably correct. Both had symptoms very suggestive of urinary tract infection, and pure growths of Escherichia coli were obtained. One of them produced two positive non-catheter specimens, each with bacterial counts of $10^{10} / \mathrm{ml}$. Imperfections in the catheterization technique with the escape of Polybactrin into the bladder might account for the occurrence of occasional false bacteriological negatives in catheter specimens.

The fourth section of the Table comprises seven cases in which a non-catheter specimen was negative but the catheter specimen positive. In three of these (Cases 63, 64, and 67) the urinary $\mathrm{pH}$ was 8,8 , and 7 respectively and there was an absence of cells. Thus the alkaline $\mathrm{pH}$ may have created false negativity in the non-catheter urines by reducing the cell count. In Case 66 the symptoms were very suggestive of urinary tract infection, and in Case 68 the criteria in the non-catheter specimen of urine just missed being positive. In the remaining cases (Nos. 62 and 65) there was no additional supportive evidence in either direction and the catheter urine is thought to be the valid one.

Thus there was correspondence between catheter and noncatheter specimens in 54 of the 68 cases $(80 \%)$. Excluding
Cases 59 and 61 , five $(7 \%)$ of the non-catheter specimens gave false-positive results and seven $(10 \%)$ false-negative results.

As a check on the cases which were catheterized and thought to be non-infected three successive non-catheter specimens of urine were obtained from each six weeks later. These showed no evidence of infection.

\section{Discussion}

In the collection of urine from young children, particularly females, the use of adhesive plastic bags is the simplest procedure, but even when the bags are removed as soon as urine is passed into them a considerable amount of contamination has already occurred (Braude et al., 1967). Ideal " clean-catch" midstream specimens from girls can at times be obtained only after many attempts and many hours of patience. Where such specimens are very carefully collected by specially trained nursing staff, after preparation of perineum and vulva with antiseptic solution, bacterial counts approximate to those found in specimens obtained by catheter and suprapubic aspiration (Pryles and Steg, 1959 ; Pryles et al., 1959, 1961), but there are many circumstances where it is difficult or impossible to obtain such specimens-in the home, the busy outpatient department or ward, with refractory children. Criteria applicable to specimens obtained from adults and to "ideal" specimens from children are often widely applied to routine specimens, so that a false-positive diagnosis of urinary tract infection is a very frequent occurrence in paediatric practice. There does, therefore, appear to be a case for setting standards by which bag urines and midstream urines which may not be entirely ideal can be used in making the diagnosis of urinary tract infection.

Cell counts and $\mathrm{pH}$ must be on fresh specimens, and bacterial counts be carried out within half an hour of micturition, or if a longer time is to elapse the urine must be refrigerated at $4^{\circ} \mathrm{C}$. This can be simply achieved during transmission to a laboratory by placing the specimen in its container in a vacuum flask containing an ice pack.

With these methods it seems likely that the diagnosis of urinary tract infection can be made in a high proportion of cases from examination of a single routine specimen of urine. If it is accepted that 32 of our cases were in fact suffering from urinary tract infection $25(78 \%)$ were effectively diagnosed in this way. As regards the five false-positives, two showed a mixed growth in the urine, which should always raise diagnostic doubts, and in two a second non-catheter specimen was negative.

Of more importance are the seven (10\%) false-negatives. Clearly if a certain amount of contamination is accepted in a large majority of specimens and standards for cell and bacterial counts are adjusted accordingly a specimen which, by accident as it were, is collected ideally may show lower cell and bacterial counts in the presence of infection, corresponding more to the standards in specimens obtained by catheter. A high urinary $p \mathrm{H}$ may also predispose to false negativity.

Recognizing that in a small number of infected cases cell and bacterial counts from single non-catheter specimens will not reach the diagnostic standards which have been set, there would need to be a safeguard in the use of these standards. We suggest a "re-examination" standard which, though it would not indicate infection, would indicate the need to obtain a further specimen of urine before a diagnosis could be made. A suitable standard for this would be a cell count of 10 or higher/cu. $\mathrm{mm}$. combined with a bacterial count in males of $10^{5}$ or more $/ \mathrm{ml}$. and in females of $10^{6}$ or more $/ \mathrm{ml}$. That these standards are not suitable for making a diagnosis of urinary tract infection is shown by the fact that over $60 \%$ of the non-infected cases reached them.

The opinion is widely held that catheterization of the bladder is an important cause of urinary tract infection (Ansell, 1962). The risk of infection in children has probably been overstated 
(Pryles et al., 1959), though it was thought to be $7 \%$ in one series (Virtanen et al., 1962). The method of catheterization which we have used has been widely and successfully employed in the catheterization of paraplegic patients, in whom the risk of infection is very high (McLeod et al., 1963). Though catheterization of the urinary bladder is undesirable for other reasons as well as the possible risk of infection, there are instances where it is indicated. One of these would be continuing doubt about the diagnosis of urinary tract infection in children after the examination of non-catheter specimens. The method described here seems to be a safe and practical one.

\section{Summary}

Non-catheter (bag or midstream specimen) and catheter specimens of urine from 68 children suspected to be suffering from infection of the renal tract have been compared. Accepting the catheter specimen predominantly as the indicator of urinary tract infection, it was concluded that 32 children $(47 \%)$ were suffering from pyelonephritis.

With the use of certain specified diagnostic criteria on single non-catheter specimens of urine $25(78 \%)$ of the infected cases were diagnosed positively. In the 68 cases there were only five (7\%) false-positives among the non-catheter specimens, suggest- ing that the criteria used reduce significantly the high incidence of false-positive results which tends to occur with random noncatheter specimens.

Means by which false-negative results can be avoided include a "re-examination" standard and consideration of urinary $\mathrm{pH}$.

A method of bladder catheterization in children with the use of a Polybactrin technique appears to be safe and can be used in cases where diagnoses cannot be readily established from non-catheter specimens.

J.W.M. wishes to thank the Royal Society for a grant for expenses, the M.R.C. for the provision of technical assistance, and Messrs. Calmic for supplies of Polybactrin G.U.

RBFERENCES

Ansell, J. (1962). 7. chron. Dis., 15, 675.

Braude, H., Forfar, J. O., Gould, J. C., and McLeod, J. W. (1967). Brit. med. Y., 4, 697

Gould, J. C."(1965) Brit. F. Urol., 37, 7.

McLeod, J. W., Mason, J. M., and Pilley, A. A. (1963). Lancet, 1, 292

Pryles, C. V., Atkin M. D., Morse, T. S., and Welch, K. J. (1959). Pediatrics, 24, 983. Pediatrics, 24, 983. Alkan, M K. (1961). Ibid., 27, 17. and Steg, N. L (1959). Ibid., 23, 441 .

Virtanen, S., Oksanen, T., and Peltunen, T. (1962). Ann. Paediat. Fenn. 8, 269.

\title{
"Clean Catch" Urines in the Newborn-Bacteriology and Cell Excretion Patterns in First Week of Life
}

\author{
GILLIAN CRUICKSHANK,* M.B., B.CH., D.C.H. ; ELIZABETH EDMOND, $†$ M.B., CH.B.
}

Brit. mod. Э., 1967, 4, 705-707

Urinary tract infection in the newborn may not be uncommon (Stansfeld, 1954, 1966 ; Lincoln and Winberg, 1964a; Smellie et al., 1964). Clinical signs mav be variable or absent, and diagnosis depends on the demonstration of a significant bacteriuria. However, in the absence of a reliable and simple method of collection of specimens diagnosis is difficult. Catheterization and suprapubic puncture are probably not acceptable as routine procedures (Pryles, 1965). The reliability of three supervised "clean catch" specimens of urine in the newborn has been assessed by bacteriological techniques, with particular reference to the problem of contamination. At the same time the urinary cell-excretion pattern in the first week of life was studied by means of a differential staining technique (Prescott and Brodie, 1964).

\section{Method}

Forty babies (21 male and 19 female) who were free from recognized infection and not receiving antibiotics were included in the study. Details of delivery and drug therapy in the mother were noted. A clean-catch specimen, personally supervised by one of us, was collected from each baby on the second, fourth, and sixth day of life. The buttocks and perineum were well cleansed with soap and water only, the labia were separated, but the foreskin was not retracted. The skin was dried with a sterile swab. The baby was supported with the

\footnotetext{
- Paediatric Registrar, Elsie Inglis Maternity Hospital, Edinburgh. Present appointment: Scientific Staff, Medical Research Council, Western General Hospital, Edinburgh.

t Registrar in Bacteriology. Central Microbiological Laboratory, Western General Hespital, Edinburgh.
}

thighs abducted, and any urine passed was collected directly into a sterile container, which was not allowed to come into contact with the baby's skin at any time. If no urine was passed within 20 minutes the baby was rewashed or the collection postponed until a more opportune moment. Urine specimens were discarded if there was a simultaneous bowel movement and further specimens collected only after rewashing.

The collected specimen was divided into two portions. One was refrigerated and transported to the bacteriological laboratory in a cooled vacuum flask. A maximum of four hours occurred between collection and plating. Quantitative bacteriological culture was carried out as described by Urquhart and Gould (1965). Blood agar and MacConkey plates were inoculated and incubated aerobically for 24 hours. The second portion was examined microscopically within two hours of collection. For staining, 2:7-diaminofluorene phloxine- $B$ was used as described by Prescott and Brodie (1964), thereby allowing differentiation of leucocytes and renal tubular cells. Examination of the uncentrifuged, well-shaken, and stained urine was carried out on an improved Neubauer counting-chamber, counting five squares and multiplying by two (Lawson and Hewstone, 1964).

\section{Results}

One hundred and twenty "clean catch" specimens were collected from the 40 babies. A total of 103 specimens $(86 \%)$ produced on culture a colony count of $10^{4}$ organisms per ml. or less, and 71 of these specimens $(59 \%)$ produced no growth on culture (Table I). If a level of $10^{5}$ organisms per $\mathrm{ml}$. is 